\title{
Effects of recreational scuba diving and snorkeling on coral reefs of the sheltered bays of the Red Sea, Egypt
}

\author{
Mahmoud H. Hanafy \\ Department of Marine Science, Faculty of Science, Suez Canal University, Ismailia, \\ Egypt
}

\section{ABSTRACT}

Due to the scarcity of the proper access point to the deep waters by divers and snorkelers, bays and lagoons are used as sheltered marine areas in the southern Egyptian Red Sea and are represented very valuable recreational areas. With the recent booming in tourism along the Egyptian coast of the Red Sea, the sheltered bays and lagoon reefs are tremendously impacted by recreational SCUBA diving activities. Three bays with similar environmental and topographic characteristics, but with different levels of diving and snorkeling activities were selected to study the impacts of recreational SCUBA diving on sedimentation rate, substrate analysis, coral cover, diversity, coral recruitment and coral reef fish assemblages.

In addition to the expected physical damage causes by incidental contacts to corals by divers, the results showed that increasing sedimentation rate as a result of intensive SCUBA diving also caused a serious impact on coral reef communities of the surveyed bays. Highest sedimentation rate was estimated at the over-dived site of the Marsa Um El-Gurifat (approximately 51,000 divers per year). Walking and standing of divers on the sea floor was disturbing the fine sediments of the bay floor, increasing turbidity and sedimentation rate on the nearby coral reefs of the bay. High sedimentation rate on the reefs of Marsa Um El-Gurifat caused the following: reduced the coral cover; overgrown soft coral that dominated coral cover, reduced the recruitment of new coral colonies, increased dead coral cover, increased the macroalgal cover especially on the reef flat areas, decreased the diversity of hard coral and coral reef fishes, shifted the fish assemblage toward higher occurrence of herbivore fishes comparing with corallivore and carnivore ones.

Keywords: Red Sea, recreational diving, sedimentation, coral health, regulated diving, Egypt.

\section{INTRODUCTION}

Coral reef ecosystem of the Egyptian Red Sea coast represents one of the most important ecological and economical resources of the country. Corals are not only one of the most productive ecosystems on earth, providing nursery grounds for fishes and invertebrates, but act as a buffer zone that protect coastal areas from erosion (Naim et al., 2000; Spalding et al., 2001), and also offers huge recreational opportunities that attract tourists (Bellwood et al., 2004). Corals are very sensitive marine animals and require particular combinations of environmental conditions to survive. Naturally, corals thrive in clear, warm and pollution free waters with low nutrients (Gleason, 1998; Nybakken and Bertness, 2005). The presence of hard substrate is also essential for coral existence (Nybakken and Bertness, 2005). Despite being considered one of the most resilient ecosystem surviving major environmental events such as ice age, meteor strikes and changes in solar activities, reefs are degraded worldwide in accelerating rates mainly because of human activities (Naim et al. 2000; Roberts et al. 2002; McCulloch et al. 2003; Cole 2003; Sheppard 2003). 
Increases in human populations and coastal development along the Egyptian coast of the Red Sea over the past 10 years have intensified the pressure on corals environmental requirements, and threaten the health and viability of coral reefs. Rubbish and other by-products of human activities in coastal areas cause many problems for the coral reef ecosystem (Thomsen and McGlathery, 2005). The Egyptian Red Sea coast, with its unique climate and remarkable fringing reef systems has become a popular tourist destination because of reef related activities such as snorkeling and SCUBA diving (Ridzwan, 1993). Millions of divers are certified every year as SCUBA diving became a conventional sport. Kotb et al. (2001) evaluated the status of the Egyptian reefs of the Red Sea. The coral reefs of Egypt are under increasing pressure from rapidly expanding tourism industry, which is also an extremely important economic activity (Kotb et al., 2008). Damage occurs from direct impact of divers and snorkelers, and indirect impacts caused by developing tourism facilities including landfill, dredging for artificial beaches, boat anchors and grounding, and sedimentation (Kotb et al., 2008). Research showed that more than $74 \%$ of divers contact the reef at least once during their dives with some parts of their body or equipments (Friedlander \& DeMartini 2002; Gardner et al. 2003; Bellwood et al. 2004). Beginner divers are causing more damage than experienced ones and divers using cameras tend to have more contacts than those not using a camera, with almost all contacts resulting in the re-suspension of sediments (Aronson \& Precht 2006; Cinner \& McClanahan 2006; Mora et al.2006; Lesser et al. 2007).

With intensifying the coastal development, human impact on the southern coasts of the Egyptian Red Sea is expected to increase, discriminating among stressors will be crucial to emphasize conservation strategies and effectively mitigate the degradation of coral reefs (Palumbi 2005; Aronson and Precht 2006). In the present study, three bays with different levels of SCUBA diving and snorkelling activities were selected to examine the impact of these activities on coral reef communities.

\section{MATERIALS AND METHODS}

\section{Study area}

The Red Sea shore is characterised by existing fringing reef which frequently interrupted by a series of lagoons and bays (sharms/marsas) mainly facing the flood pathway (valleys or wadis). These coastal features are formed usually at the opening of the valleys under the influence of floods. Such bays are considered as traps for sediment loading by the fresh water run-off during flooding and produced soft bottom habitat in the west and middle area of the bay, while the side walls provide a hard substrate for coral growth.

The edges of the fringing reefs of the Egyptian Red Sea are highly exposed to surface current and wave, except in the areas of bays and lagoons. Therefore, these lagoons and bays represent essential areas for tourism development, mainly because its represent the most safe access points to the deep waters by divers and snorkelers as well as they are the only areas possess proper sandy beaches. To study the impact of diving on coral reefs, three bays with similar features and structure, but with different level of diving rates (number of dives/year) were investigated. The three bays are located along the southern coast of the Egyptian Red Sea and between the two cities of El-Qusier and Marsa Alam, namely Marsa Um El-Gurifat, Marsa Shagra and Marsa Sefeen (Fig.1). 


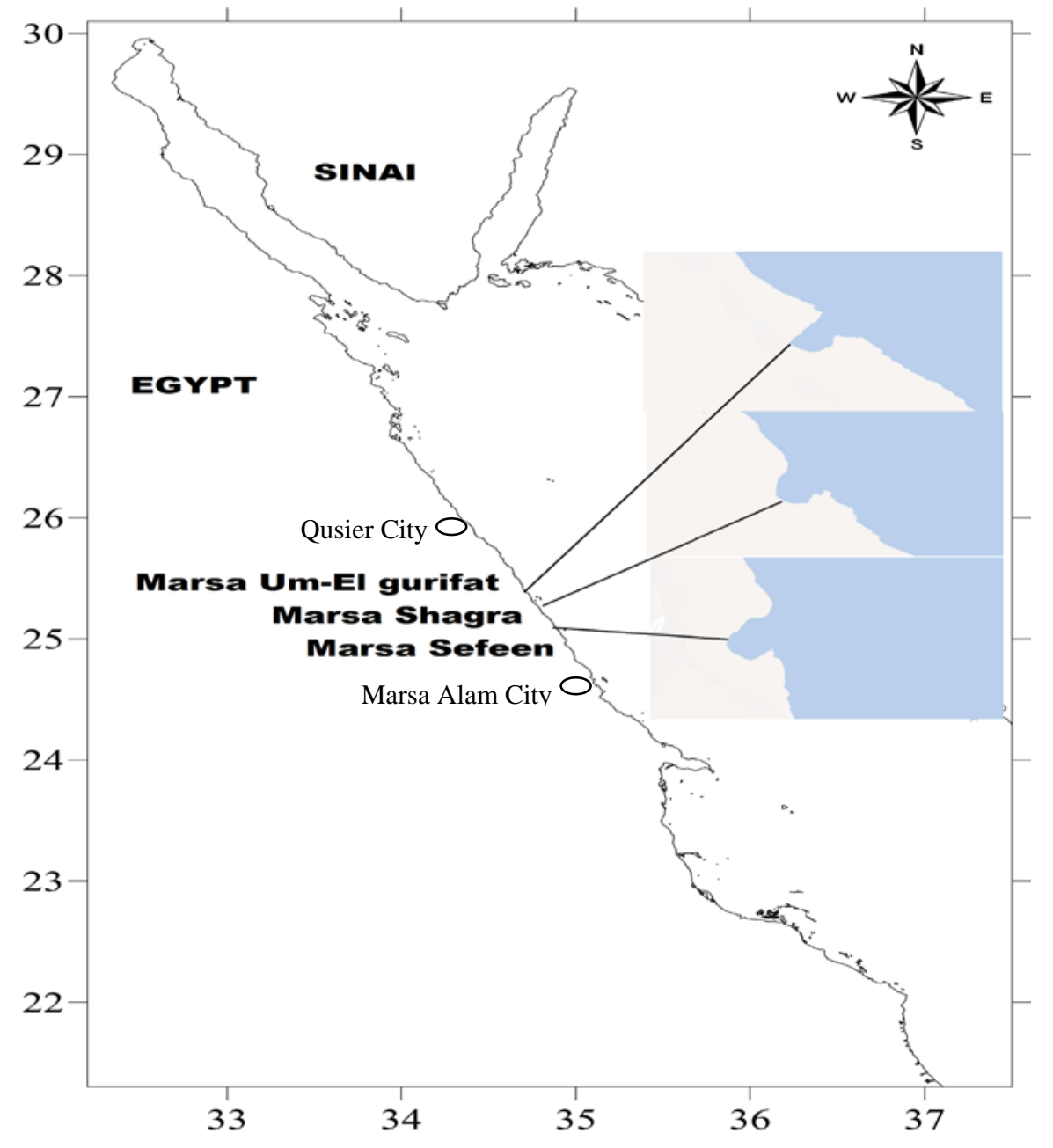

Fig. 1: Location of the three studied bays

\section{Impact assessment}

At each studied site, two sub-sites lay in the north and south of each bay were surveyed using scuba-diving techniques. Line Intercept Transect techniques parallel to the shoreline was used to study the status of the coral reef communities. The abundance and diversity of coral reef fishes were determined in three $100 \mathrm{~m} / 5 \mathrm{~m}$ wide (i.e $500 \mathrm{~m}^{3}$ ) Belt Transect for fish community at each sub-site. Benthic analyses were estimated in each sub-site at the three zones of reef flat, reef edge and reef slope. Estimation of the benthic components in each zone was conducted by using three line intercept transects, based on English et al. (1997). In addition, the numbers of the newly recruited colonies were estimated at the reef edge and reef slop, using three $25 \mathrm{~m}$ belt transect and described on a basis of number of recruited colonies $/ \mathrm{m}^{2}$. The level of impact was quantified by calculating the annual number of diver/site, according to the dive operators and the sedimentation rate at each sub-site.

\section{Sedimentation rate}

Sediment traps have been shown to provide adequate measurement of relative spatial and temporal variability of sediment fallout (Woolfe and Larcombe, 1998). At each sub-site, sedimentation rate was estimated using sediment traps according to English et al. (1997). Four sediment trapping bottles were installed at depths 5-10m of each sub-site, and remained upright with fixed position underwater. Each sediment trap was covered with an iron-mesh netting (mesh size of $1 \mathrm{~mm}$ ) and secured by rubber bands. The netting was used to prevent fishes, crustaceans or molluscs from 
entering and re-suspending the sediment collected in the bottles. After one month, the sediment traps were collected and sedimentation rates as $\mathrm{mg} / \mathrm{cm}^{2} / \mathrm{day}$ were determined by dividing the dry weight (in mg) with the area of the sediment trap aperture width (in $\mathrm{cm}^{2}$ ) over the duration (in days).

\section{RESULTS}

\section{SCUBA diving impact and sedimentation rate:}

As a result of the direction of the prevailing wind (north-east to south west), the reef edge of the fringing reefs are highly exposed to surface current and waves. This makes access to the open water by swimmers, snorkelers and divers are so dangerous. Therefore, lagoons and bays represent proper access points to recreational marine activities. With intensifying tourism development around and on these bays and lagoons due to accessibility to deep water as well as availability of beaches, recreational activities especially diving and snorkelling became one of the most serious threats to the sensitive habitats especially coral reefs.

Diving rates extremely varied between the three investigated bays. The highest diving rate, of approximately 51,000 dives/site/year, was recorded at Marsa Um ElGurifat comparing with less than 20,000 dives/site/year at Marsa Shagra and almost nil at Marsa Sefeen (Fig. 2). In addition, intensive swimming and snorkelling activities were observed in the bay of Marsa um El-Gurifat. It is observed that divers at Marsa Um El-Gurifat stand up and settled more frequently on the sea floor disturbing and stirring the sea floor sediment causing large turbidity. This is mainly due to that most of the divers are beginners and the bay is used as diving training area. Sedimentation rates were highly varied between the three surveyed sites (ANOVA: $\mathrm{P}<0.001)$.

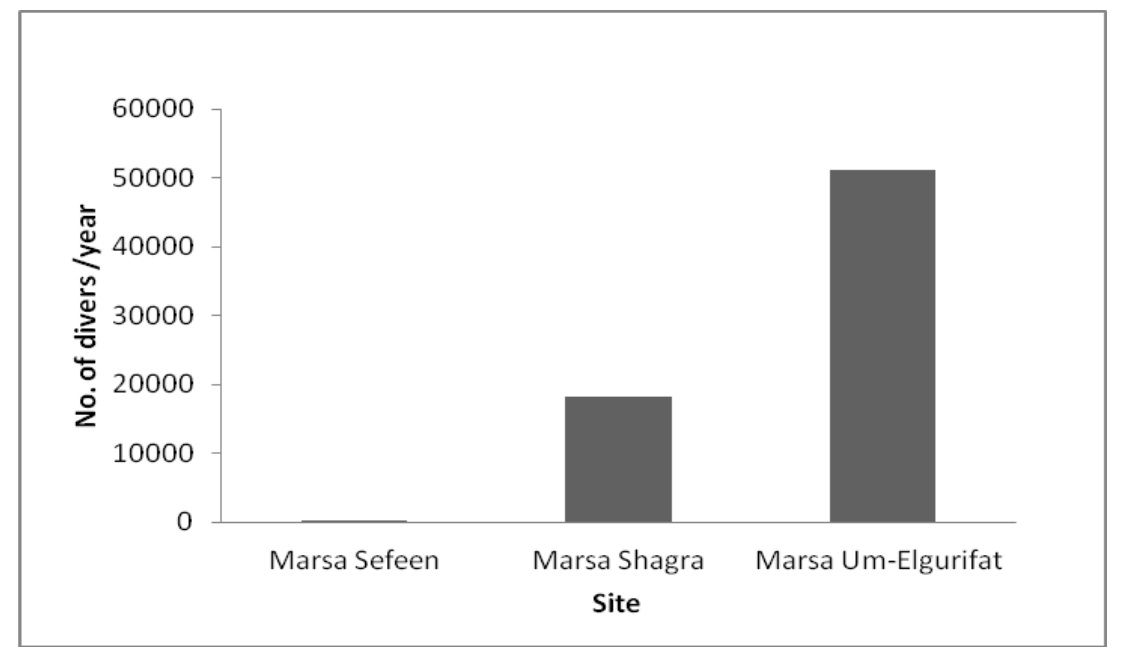

Fig. 2: Annual diving rates on the reefs of the three surveyed bays in the study area (Source: Diving centers operate on the studied bays)

In general, it was obvious that the sedimentation rates were influenced by the diving rate, i.e the high diving rate and the high sedimentation rate. Highest rate of sedimentation with an overall mean of $228.9 \pm 24.7 \mathrm{mg} / \mathrm{cm} 2 /$ day was estimated at the bay of Marsa Um-Gurifat, compared with $85.3 \pm 7.7$ and $38.8 \pm 5.9 \mathrm{mg} / \mathrm{cm} 2 /$ day estimated at Marsa Shagra and Marsa Sefeen, respectively. Obvious trend of increasing sedimentation rates on the southern reefs rather than the northern reefs of 
the studied sites noticed. The maximum sedimentation rate of $240.3 \pm 26.9$ $\mathrm{mg} / \mathrm{cm} 2 /$ day was recorded at the southern sub-site of Um El-Gurifat, while the lowest rate of $28.9 \pm 6.5 \mathrm{mg} / \mathrm{cm}^{2} /$ day was estimated on the reef of the northern sub-site of Marsa Sefeen (Fig. 3).

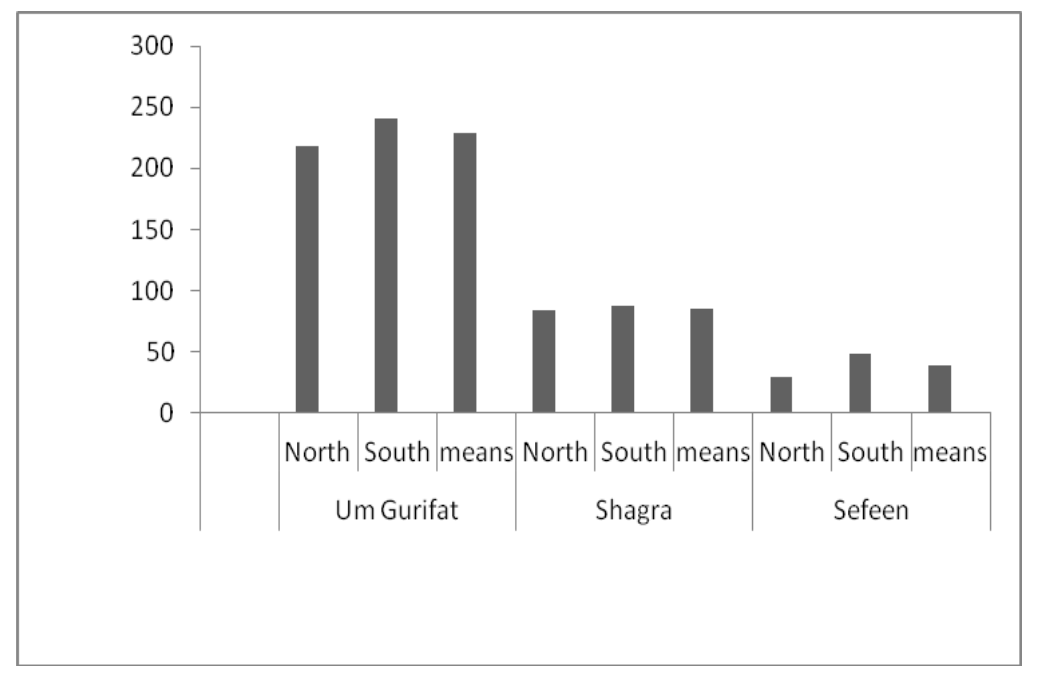

Fig. 3: Sedimentation rates (mg/ $\mathrm{cm}^{2} /$ day) estimated on the surveyed north and south sub-sites/reefs of the three bays under investigation, and the estimated mean for each bay.

\section{Cover area of benthic live forms}

The living benthic coverage varied significantly between the studied sites and sub-sites (north and south of each bay) as well as between reef zones (reef flat, edge and slop). The highest overall mean of the percentage cover of living substrate was recorded at the reefs of Marsa Shagra (68.4\%), while the lowest cover was estimated at the reefs of Marsa Um El-Gurifat and Marsa Sefeen, with overall means of 54.5 and $62.0 \%$ to the total cover, respectively (Table 1). In general, hard coral cover dominated the living organisms at all sites, sub-sites and zones, except the site of Marsa Um El-Gurifat. The lowest occurrence of hard coral cover of an overall mean of $15.8 \%$ was estimated at the reefs of Marsa Um El-Gurifat, compared with the overall means of 57.8 and $53.0 \%$ to the total cover at the reefs of Marsa Shagra and Marsa Sefeen, respectively (Table 1). Occurrence of soft coral found to be depended on the sedimentation rates, i.e the high sedimentation, the high coverage of soft corals. The highest coverage of soft coral was recorded at Marsa Um El-Gurifat, averaged with about 33.7\% compared with 8.9 and $7.3 \%$ at the reefs of Marsa Shagra and Marsa Sefeen, respectively (Table 1).

On the sub-site level, the occurrences of living substrate and hard coral cover showed a general trend of higher occurrence in the northern than the southern subsites at all reefs of the studied bays. In contrast, occurrence of soft coral showed different trend where the percentage cover area found to be mostly higher on the southern reefs rather than the northern reefs, especially at the reefs of Marsa Um ElGurifat (Table 1 and Fig.4).

Comparing of the occurrence of different living substrate types showed significant difference between zones (ANOVA: $\mathrm{P}<0.001$ ). On the reef flat, the highest occurrence of living coral covers were recorded at the two sub-sites of Marsa Shagra, while the lowest occurrence were estimated on the reef flat of the south sub-site of Marsa Um El-Gurifat. It was obvious that macroalgal cover occurred extremely higher on the reef flat of north and south reefs of Marsa Um El-Gurifat (being 10 and 
$20 \%$ of the total cover, respectively), comparing with the other two bays (Table 1 and Fig.4 ). Hard coral cover dominated the substrate of the reef edge in all surveyed reefs except the reefs of Marsa Um El Gurifat where soft coral dominated the living substrate. Similar trend was observed on the reef slope, where hard coral cover dominated the reef slops in the two bays of Marsa Shagra and Marsa Sefeen, and soft coral cover dominated the living substrate on the north and south reefs of the Marsa Um El-Gurifat (Table 1 and Fig. 4). It was also noticed that soft coral overgrown the hard coral colonies. The substrate analysis indicated obviously that highest soft coral and macroalgal covers linked with the highest sedimentation rates recorded at Marsa Um El Gurifat.

Table 1: Substrate analysis as percent covers (\%) of different substrate types estimated at the three reef zones (reef flat, RF; reef edge, RE; reef slope, RS) of the surveyed north and south reefs of the three bays under investigation.

\begin{tabular}{|c|c|c|c|c|c|c|c|c|c|c|c|c|c|c|c|c|c|c|c|c|c|}
\hline \multirow{3}{*}{$\begin{array}{l}\text { Site } \\
\text { Sub-site } \\
\text { Zone }\end{array}$} & \multicolumn{7}{|c|}{ Marsa Um El Gurifat } & \multicolumn{7}{|c|}{ Marsa Shagra } & \multicolumn{7}{|c|}{ Marsa Sefeen } \\
\hline & \multicolumn{3}{|c|}{ North } & \multicolumn{4}{|c|}{ South } & \multicolumn{3}{|c|}{ North } & \multicolumn{3}{|c|}{ South } & \multirow[b]{2}{*}{ mean } & \multicolumn{3}{|c|}{ North } & \multicolumn{3}{|c|}{ South } & \multirow[b]{2}{*}{ mean } \\
\hline & RF & RE & RS & RF & RE & RS & Mean & RF & RE & RS & RF & $\mathbf{R E}$ & RS & & RF & RE & RS & RF & RE & RS & \\
\hline live hard coral & 30 & 24 & 10 & 5 & 16 & 10 & 15.8 & 50 & 70 & 59 & 45 & 67 & 56 & 57.80 & 30 & 74 & 62 & 20 & 71 & 60 & 53.00 \\
\hline live soft coral & 5 & 40 & 45 & 10 & 45 & 57 & 33.7 & 5 & 7 & 11 & 5 & 11 & 15 & 8.90 & 5 & 9 & 7 & 5 & 8 & 9 & 7.30 \\
\hline Algae & 10 & $\mathbf{0}$ & o & 20 & o & 0 & 5 & 5 & o & o & 5 & $\mathbf{0}$ & 0 & 1.70 & 5 & o & o & 5 & o & o & 1.70 \\
\hline Non -living substrate & 55 & 36 & 45 & 65 & 39 & 33 & 45.5 & 40 & 23 & 30 & 45 & 23 & 29 & 31.70 & 60 & 17 & 31 & 70 & 21 & 31 & 38.00 \\
\hline dead coral & 15 & 16 & 25 & 30 & 19 & 28 & 22.7 & 2 & 15 & 10 & 10 & 18 & 21 & 12.70 & 25 & 17 & 31 & 30 & 21 & 31 & 26.00 \\
\hline Rock & 40 & 20 & 15 & 25 & 20 & 5 & 20.8 & 28 & 8 & 20 & 30 & 5 & 8 & 16.50 & 30 & 0 & 0 & 30 & 0 & 0 & 10.00 \\
\hline Sand & 0 & 0 & 5 & 10 & 0 & 0 & 2.6 & 10 & 0 & 0 & 5 & 0 & 0 & 2.50 & 5 & 0 & 0 & 10 & 0 & 0 & 2.50 \\
\hline $\begin{array}{l}\text { No. of } \quad \text { new } \\
\text { recruitment } / \mathrm{m} 2\end{array}$ & & 1.5 & 0.5 & & 1.2 & 0.4 & 0.9 & & 2.4 & 2.1 & & 2.3 & 1.9 & 2.20 & & 2.1 & 2.3 & & 2.1 & 2.4 & 2.20 \\
\hline
\end{tabular}
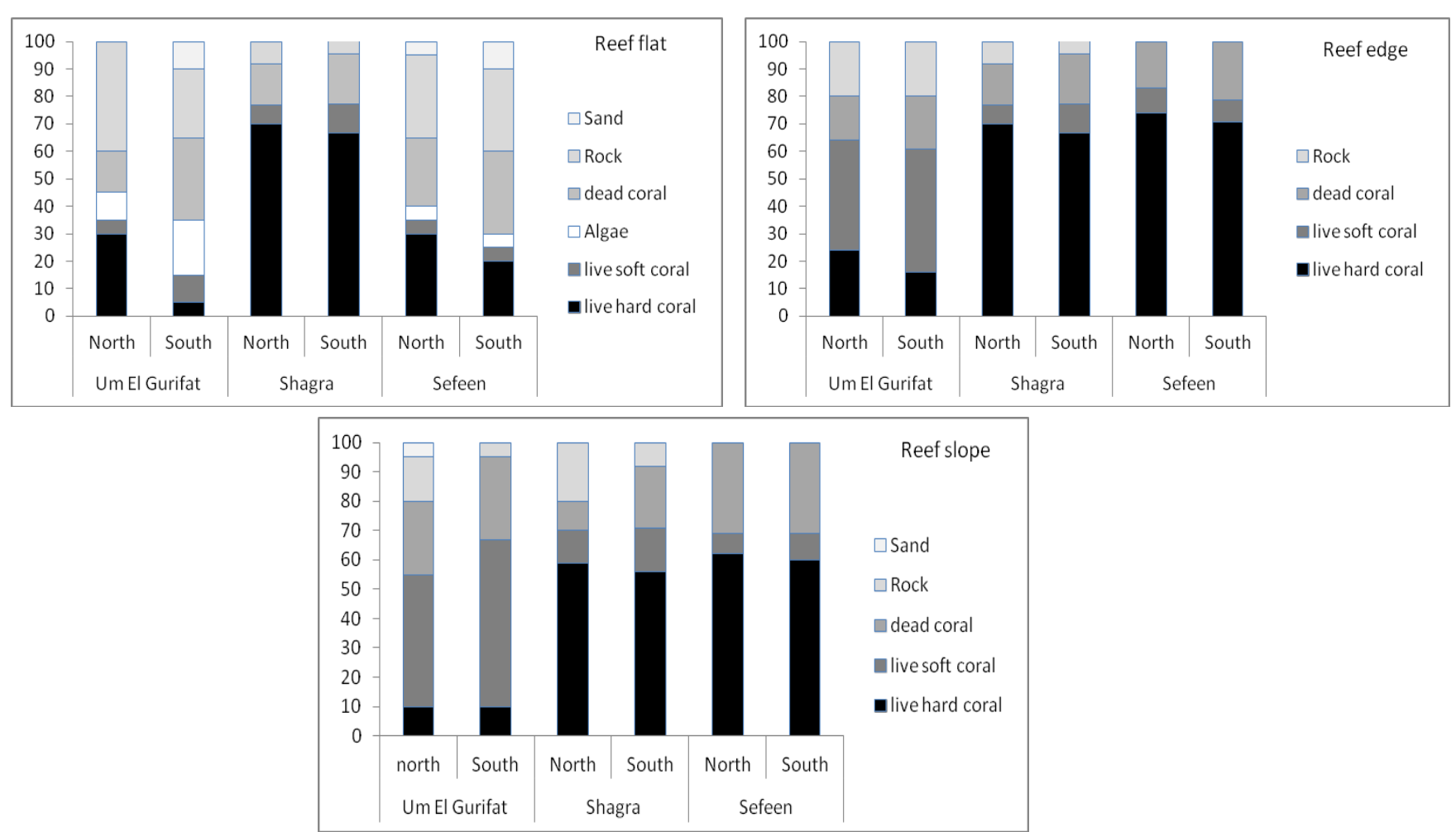

Fig. 4: Percentage covers (\%) of the different substrate types recorded at the three zones of the north and south sub-sites of each investigated bay 


\section{Coral recruitment}

The estimated coral recruitment at the two zones of reef edge and reef slope of the surveyed reefs varied significantly (ANOVA: $\mathrm{P}<0.01$ ) between the sites under investigation. Highest overall means of 2.35 and 2.2 colonies $/ \mathrm{m}^{2}$ were estimated on the reefs of Marsa Shakara and Marsa Sefeen, respectively. In contrast lowest recruitment was estimated at Marsa Um El Gurifat, averaged 0.9 colony $/ \mathrm{m}^{2}$ (Fig. 5)

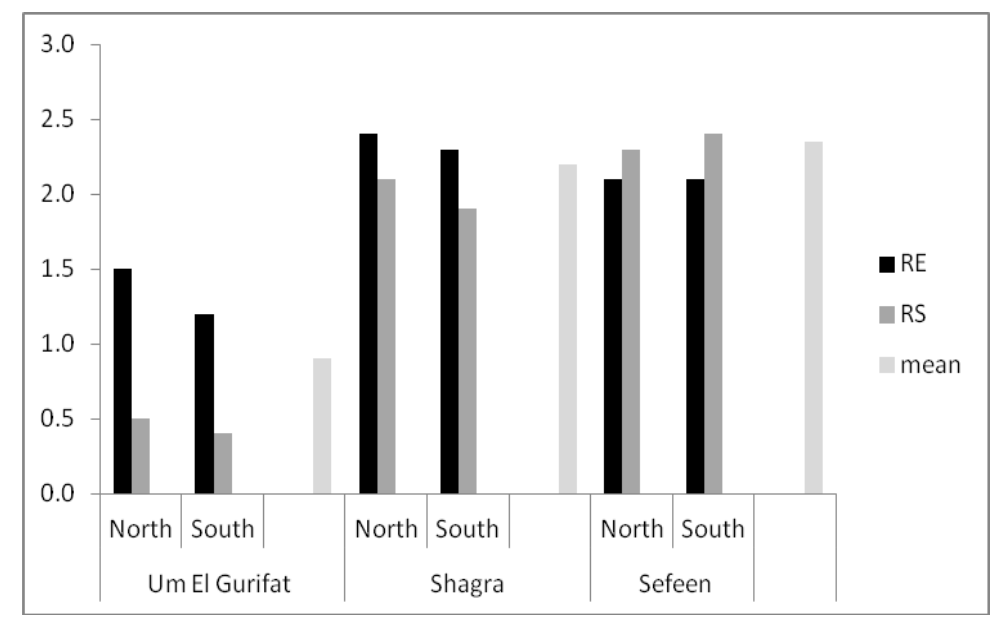

Fig. 5: Coral recruitment (number of new colonies $/ \mathrm{m}^{2}$ ) counted on the reef edge and reef slope of all survey sub-site reefs (north and south) of each bay, and the estimated average for each studied site

\section{Diversity and fish abundance}

The diversity in hard coral showed lowest numbers of genera on the north and south reefs of Marsa Um El-Gurifat, being 6 and 7 genera, respectively. At the other surveyed sub-sites hard corals were represented by 13 genera on the north reef of Marsa Shagra and 12 genera on the other surveyed reefs. Soft coral represented only by 3 genera on the north of Marsa Um El-Gurifat and Marsa Shagra, and only 2 genera at the other sub-sites (Table 2).

Table 2: Diversity of coral (as number of genera) and coral reef fishes (as number of fish species), and abundances of coral reef fishes as well as abundance of fishes (count/500m) with different feeding habits estimated on the coral reefs of the surveyed sub-sites.

\begin{tabular}{|l|l|l|l|l|l|l|}
\hline & \multicolumn{2}{|l|}{ Marsa Um El Gurifat } & \multicolumn{2}{l|}{ Marsa Shagra } & \multicolumn{2}{l|}{ Marsa Sefeen } \\
\hline Diversity & North & South & North & South & North & South \\
\hline Hard Coral diversity & 6 & 7 & 13 & 12 & 12 & 12 \\
\hline Soft coral diversity & 3 & 2 & 3 & 2 & 2 & 2 \\
\hline Fish Diversity & 69 & 67 & 72 & 75 & 74 & 74 \\
\hline Fish Abundance & 149 & 152 & 143 & 138 & 147 & 160 \\
\hline Herbivore fishes & 112 & 110 & 50 & 48 & 56 & 62 \\
\hline carnivore fishes & 25 & 29 & 64 & 58 & 59 & 63 \\
\hline Corallivore fishes & 12 & 13 & 29 & 32 & 32 & 35 \\
\hline
\end{tabular}


Fish diversity, as a number of fish species, was ranged between the highest records of 75 species at the south reef of Marsa Shagra, to the lowest record of 67 species at the south reef of Marsa Um El-Gurifat. Fish abundance varied slightly and non-significantly between different sub-sites. It was ranged between lowest abundance of 138 at the south reef of Marsa Shagra and $160 \mathrm{fish} / 500 \mathrm{~m}^{3}$ at the southern reef of Marsa Sefeen. Although, there was no significant difference in fish abundance between surveyed sites as well as between the sub-sites (ANOVA: $\mathrm{P}>0.05$ ), the obvious difference was recorded on the level of occurrence of fishes with different feeding habits. Herbivore fishes were dominated the fish assemblage on the reefs of Marsa Um El Gurifat. Highest occurrences of herbivore fishes were recorded on the north and south reefs of Marsa Um El-Gurifat averaged 73.8\% compared with 34.9 and $38.4 \%$ to the total fish count on the reefs of Marsa Shagra and Marsa Sefeen, respectively (Fig.6). In contrast, the lowest occurrence of carnivore and corallivore fishes were estimated on the reefs of Marsa Um El-Gurifat, averaged 17.9 and 8.3\% to the total abundance of fishes, compared with 43.3 and $21.8 \%$ on the reefs of Marsa Shagra and 39.8 and $21.8 \%$ averaged on the reefs of Marsa Sefeen, respectively (Fig.6)

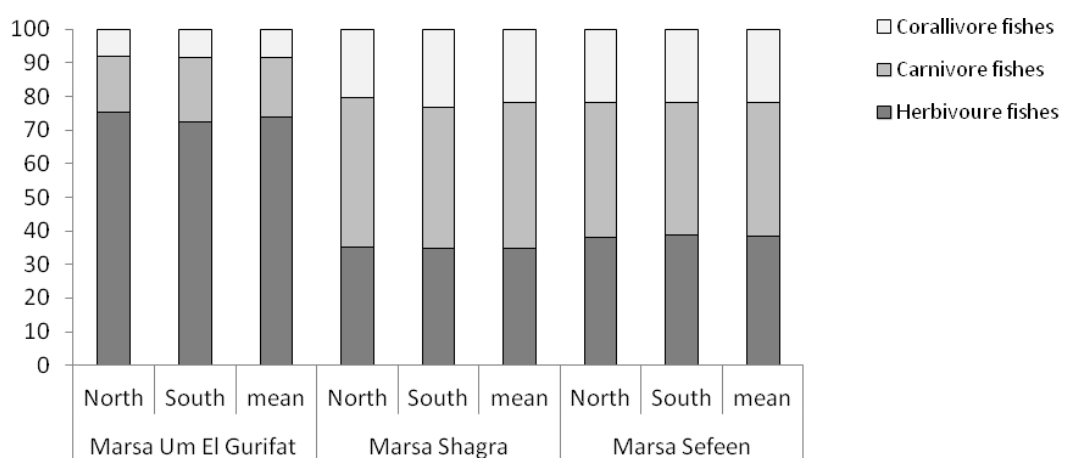

Fig. 6: Percentage of occurrence (\%) of each fish feeding category to the total abundance of coral reef fishes at the surveyed north and south sub-sites of each bay and the overall calculated mean for each surveyed bay.

\section{DISCUSSION}

Worldwide declines in coral coverage and overall reef degradation can be attributed to a variety of anthropogenic and natural causes (Pandolfi et al., 2003; Côté et al., 2005). Numerous studies revealed that heavy sedimentation resulted from diving activities and coastal development is linked to various types of reef degradation; shading of adult corals (Rogers, 1990; van Katwijk et al. 1993; West and Van Woesik, 2001), fewer coral species, less live corals, lower coral growth rates, greater abundance of branching forms (Acevedo et al. 1989; Torres et al. 2002; ISRS 2004; Nybakken and Bertness, 2005; Rachello- Dolmen et al. 2007), reduced depth ranges (Anthony and Fabricius 2000; Edinger et al. 2000) decreased calcification, decreased net productivity of corals, and slower rates of reef growth (Edinger et al., 1998, Subade, 2007). Moreover, and probably the most severe effect of sedimentation is the inhibition of recruitment (Wittenberg and Hunte 1992; Babcock and Davies 1999; Gilmour 1999; Ward and Harrison 2000; Harrison and Ward 2001; Babcock and Smith 2002; Cox and Ward 2002). Sedimentation is therefore considered one of the most widespread contemporary, human-induced perturbations on reefs. 
Until recently, recreational SCUBA diving tourism was thought of as an activity entirely compatible with the sustainable use of marine resources, as opposed to extractive activities, such as fishing, mining, and construction of tourist facilities. However, recent evidence has demonstrated that reefs may become degraded as a result of poorly planned or intensive tourist use (Jameson et al., 1999; Tratalos and Austin, 2001). Several previously described studies quantified the level of coral physical damage by either breakage or abrasion, in the Egyptian reefs of the Red Sea due to reef walking (Woodland and Hooper, 1977; Liddle and Kay, 1987; Hawkins and Roberts, 1993 and 2004), snorkeling and diving activities (Hawkins and Roberts, 1992; Serour, 2004; Attalla, 2011). These studies provided a quantitative analysis of direct physical damage due to divers, thought to be the main causes of mortality in frequently visited dive sites. Riegl and Velimirov (1991) showed that in heavily dived sites, there were more coral breakage, algal overgrowth, and tissue loss than in low frequency dive sites. Similarly, Hawkins and Roberts (1992; 1993), showed that there was a significantly high number of damaged colonies, loose fragments, and abraded coral colonies in heavily used dive sites. Studies on the impact of sedimentation resulted from diving activities are rare worldwide. Although the Egyptian reefs of the Red Sea are considered the most famous diving destination, nothing was known on the impact of sedimentation resulted from diving activities on coral reef ecosystem.

Beside the expected direct physical damage for coral as a result to the potential contact incidents, heavily used area of the Marsa Um El-Gurifat by divers and snorkelers caused a tremendous increase in sedimentation rate comparing with the other two investigated sites of Marsa Shagra and Marsa Sefeen. It was obvious that increasing the sedimentation rate due to diving activities on the coral reefs at Marsa Um El Gurifat represented tremendous stressor to coral reefs. It is found that increasing sedimentation rate caused reducing of the hard coral cover; soft coral cover overgrown and dominated the coral assemblage instead of hard corals; macroalgal cover (algal mats) was increased especially on the reef flat zone and consequently herbivore fish occurrence was increased sharply; hard coral and coral reef diversity was declined and coral recruitment was reduced.

The results matches those done by van Katwijk et al. (1993) who recorded significant changes in coral cover, community structure and an increase number of broken corals due to sediment discharge from rivers. The domination of soft corals on heavily impacted sites by sedimentation is also supported by Schleyer and Celliers (2003) who found that soft corals cover increased and dominated the hard coral because of high sedimentation. On the reefs of Marsa Um El-Gurifat, the soft coral, mainly Xenia overgrown and dominated the living substrate.

In addition to corals, increases in sedimentation can affect other reef-associated organisms. Coverage of crustose coralline algae (which cements reefs and functions as a settlement substrate for coral planulae) is related to the sedimentary environment, with lower percent cover recorded in areas with thicker sediment deposits (Fabricius and De'ath, 2001). Declines in coral reef fish populations have been related to increased sedimentation levels (Hawkins et al., 2006.). Settlement of early-life stages of seaweeds is disrupted by high levels of sediment (Schiel et al., 2004). Even entire benthic assemblages can be altered as a result of human-induced high-sedimentation events (Colosio et al., 2007). It was found that increasing of sedimentation rate in the area of Marsa Um El-Gurifat as a result of recreational activities caused significant increase in the macroalgal cover especially in the reef flat area. Consequently, the abundance of the herbivore fishes increased sharply comparing with the other two 
sites. Vermeij et al. (2010) assessed whether herbivores are capable of reducing the abundance of turf algae at coral-algae boundaries. They found that nutrient enrichment cause significant increase in the cover of turf algae which cause visible (overgrowth) and invisible negative effects (reduced fitness) on neighboring corals, and consequently herbivore fishes.

\section{CONCLUSION}

The results of this study indicated obviously that, in addition to the physical damage due to the incident contact of divers with coral colonies, increasing sedimentation rate as a result of unregulated SCUBA diving is seriously added stressor for coral reefs, especially within the sheltered or semi-closed bays/lagoons. In conclusion, the study revealed that increasing of sedimentation rate resulted in: 1) reducing the cover percent age of the hard corals; 2) increasing the cover percent age of the more tolerant living organisms to sedimentation, i.e mainly soft corals and macroalgae; 3) reducing the coral recruitment; 4) shifting the coral reef fish structure to be dominated by herbivore fishes. Due to the highly importance of the lagoons and bays from the ecological and socio-economical points of view, new conservation strategies are required to mitigate their negative impact on coral communities.

This study uses the fringing coral reefs of the sheltered lagoons and bays of the Red Sea as a model for integrating scientific research on reef status with specific management suggestions to mitigate the current and serious impact of sedimentation resulted from diving and snorkeling on coral reef communities. These management suggestions could be included: 1) establish and implement carrying capacity plan for the lagoon and bay reefs; 2) install proper submerged structure on the soft bottom sea floor with a proper height to prevent the divers to trample and walk directly on the sea floor, consequently, stop their effect on disturbing sea floor sediments; 3) install submerged walkways to allow snorkel and divers to access the deep waters through certain points and not allow for them to get access randomly; 4) create a proper best practice guideline for diving and snorkeling the bays and lagoons; 5) Provide professionally trained guides and proper educational and outreach materials.

\section{ACKNOWLEDGEMENTS}

This work was supported by Hurghada Preservation and Conservation Association (HEPCA) through which this study was undertaken. I am deeply indebted to Dr. Ismail, M; Dr Abu El-Regal, M; Dr Abd El-Rahman, D.; Mr. Monier, T. for their support in data gathering and paper preparation.

\section{REFERENCES}

Acevedo, R.; Morelock, J. and Olivieri, R. A. (1989). Modification of coral reef zonation by terrigenous sediment stress. Palaios, 4: 92-100.

Attalla, T. M. (2011). Assessment Study on Natural and Human Impacts on the Coral Reefs of the Red Sea, Egypt. MsC Thesis, Suez Canal University, Egypt, 254 pp

Anthony, K.R.N. and Fabricius, K.E. (2000) Shifting roles of heterotrophy and autotrophy in coral energetics under varying turbidity. Journal of Experimental Marine Biology and Ecology, 252: 221-253 
Aronson R.B and Precht B.F (2006). Conservation, precaution, and Caribbean reefs. Coral Reefs, 25: 441-450

Babcock, R. and Daves, P. (1991). Effects of sedimentation on settlement of Acropora millipora. Coral Reefs, 9:205-208

Bellwood, D. R.; Hughes, T. P.; Folke, C. and Nyström, M. (2004). Confronting the coral reef crisis. Nature, 429, 827-833.

Babcock, R. and Smith, L. (2002). Efects of sedimentation on coral settlement and survivorship. Proc 9th Int Coral Reef Symp, 1:245-248

Colosio, F.; Abbiati, M. and Airoldi, L. (2007). Effects of beach nourishment on sediments and benthic assemblages Marine Pollution Bulletin 54: 1197-1206.

Côté, I.M.; Gill, J.A.; Gardner, T.A.and Watkinson, A.R. (2005). Measuring coral reef decline through meta-analyses. Philosophical Transactions of the Royal Society,360: 385-395.

Cox, E.F. and Ward, S. (2002). Impact of elevated ammonium on reproduction in two Hawaiian scleractinian corals with different life history patterns. Marine Pollution Bulletin 44: 1230 -1235

Cinner, J and McClanahan, T. (2006). Socioeconomic factors that lead to overfishing in small-scale coral reef fisheries of Papua New Guinea. Environmental Conservation, 33: 73-80.

Cole, J. (2003). Global change: dishing the dirt on coral reefs. Nature, 421: 705-706.

Edinger, E.N.; Jompa, J.; Limmon, G.V.; Widjatmoko, W. and Risk, M. (1998). Reef degradation and coral biodiversity in Indonesia: effects of land-based pollution, destructive fishing practices and changes over time. Marine Pollution Bulletin, 36 (8): 617-630.

Edinger, E. N.; Limmon, G. V.; Jompa, J.; Widjatmoko, W.; Heikoop, J.M. and Risk, M.J. (2000). Normal coral growth rates on dying reefs: Are coral growth rates good indicators of reef health? Mar Poll Bull, 40: 404-425.

English, S.; Wilkinson, C. and Baker, V. (1997). Survey Manual for Tropical Marine Resources. Aust Inst Mar Sci, Townsville.

Fabricius, K. and De'ath, G., (2001). Environmental factors associated with the spatial distribution of crustose coralline algae on the Great Barrier Reef. Coral Reefs 19: 303-309.

Gardner, T.A.; Cote, I. M.; Gill, J. A.; Gant, A.;Watkinson, A. R. (2003). Long-term region-wide declines in Caribbean corals. Science 301: 958-960

Gilmour, J. (1999). Experimental investigation into the effects of suspended sediment on fertilization, larval survival and settlement in a scleractinian coral. Marine Biology, 135: 451-462.

Gleason, D. F. (1998). Sedimentation and distributions of green and brown morphs of the Caribbean coral Porites astreoides Lamarck. J. Exp Mar Biol., Ecol 230:73-89

Harrison, P.L. and Ward, S. (2001). Elevated levels of nitrogen and phosphorus reduce fertilisation success of gametes from scleractinian reef corals. Marine Biology, 139: 1057-1068

Hawkins, J. and Roberts, C. (1992). Effects of recreational SCUBA diving on forereef Slope communities of coral reefs. Biological Conservation. 62:171-178.

Hawkins, J. and Roberts, C. (1993). Effects of recreational SCUBA diving on coral Reefs: trampling of reef flat communities. J. Applied Ecology, 30:25-30.

Hawkins, J.P. and Roberts, C. (1994), "The Growth of Coastal Tourism in the Red Sea: Present and Future Effects on Coral Reefs”, AMBIO, 23 (8): 503-508. 
Hawkins, J.P., Roberts, C.M., Dytham, C., Schelten, C., Nugues, M.M. (2006). Effects of habitat characteristics and sedimentation on performance of marine reserves in St. Lucia. Biological Conservation, 127: 487-499.

ISRS (2004). The effects of terrestrial runoff of sediments, nutrients and other pollutants on coral reefs. Briefing Paper 3, International Society for Reef Studies, pp. 18

Jameson, S., Ammar,M., Saadalla,E., Mostafa,H. and B. Riegl (1999). A coral damage index and its application to dive sites in the Egyptian Red Sea. Coral Reefs, 18:333-33

Kotb, M.; Hanafy, M. H.; Rirach, H.; Matsumura, S.; Al-Sofyani, A. A.; Ahmed, A. G.; Bawazir, G. and Al-Horani, F. A. (2008) 4. Status of coral reefs in the Red Sea and Gulf of Aden in 2004. In: Wilkinson, C. (Ed.), Status of Coral Reefs of the World: 2008. Global Coral Reef Monitoring Network and Reef and Rainforest Research Centre, Townsville, Australia, 296p.

Kotb, M.M.A.; Zeid, M. M. A. and Hanafy, M. H. (2001). Overall evaluation of the coral reef status along the Egyptian Red Sea Coast". Biologia Marina Mediterranea, Periodico edito dalla Societa Italiana di Biologia Marina, Vol. 8(1): 15-32, Sharm El-Sheikh

Lesser, M. P; Bythell, J. C.; Gates, R. D.; Johnstone, R. W. and Hoegh- Guldberg, O. (2007). Are infectious diseases really killing corals? Alternative interpretations of the experimental and ecological data. J. Exp Mar Biol Ecol., 346: 36-44

Liddle, M. and Kay, A. (1987). Resistance, survival, and recovery of trampled corals on The Great Barrier Reef. Biological Conservation, 42:1-18.

McCulloch, M.; Fallon, S.; Wyndham, T.; Hendy, E.; Lough, J. and Barnes, D. (2003). Coral record of increased sediment flux to the inner Great Barrier Reef since European settlement. Nature, 421: 727-730.

Mora, C.; Andréfouët, S.; Costello, M.J.; Kranenburg, C.; Rollo, A., Veron, J.; Gaston, K.J. and Myers, R.A. (2006). Coral reefs and the global network of marine protected areas. Science, 312: 1750-1751.

Naim, O.; Cuet, P. and Mangar, V. (2000). The Mascarene Islands. In: Obura D. O. (ed.) Coral Reefs of the Indian Ocean. Oxford Univ. Press, Oxford, 353-381.

Nybakken, J.W. and Bertness, M. D. (2005). Marine Biology - An Ecological Approach. (4th Ed.). Pearson - United States of America.

Palumbi, S. R. (2005). Coral gardens: Paternity and drug testing on the reef. Current Biology, 5: R544-R545.

Pandolfi, J. M.; Bradbury, R. H.; Sala, E.; Hughes, T. P.; Bjorndal, K. A.; Cooke, R. G.; McArdle, D.; McClenachan, L.; Newman, M. J. H.; Paredes, G.; Warner, R. R., Jackson, J. B. C. (2003). Global trajectories of the long-term decline of coral reef ecosystems. Science, 301: 955-958.

Rachello-Dolmen, P. G. and Cleary, D. F. R. (2007). Relating coral species traits to environmental conditions in the Jakarta Bay/Pulau Seribu reef system, Indonesia. Estuarine, Coastal Shelf. Sci., 73: 816-826.

Riegl, B. and Velimirov, B. (1991). How many damaged corals in Red Sea reef systems? A quantitative survey. Hydrobiologia, 216/217: 249-256.

Ridzwan, A. R. (1993). Recovery processes of coral communities following the crown-of-thorns starfish, Acanthaster planci, infestations of the east coast islands of Peninsular Malaysia. PhD thesis, University of Newcastle upon Tyne, Newcastle,UK. 
Rogers, C.S. (1990). Responses of coral reef and reef organisms to sedimentation. Marine Ecology Progress Series, 62: 185-202.

Schleyer, M. H and Celliers, L. (2003). Coral dominance at the reef-sediment interface in marginal coral communities at Sodwana Bay, South Africa. Marine and Freshwater Research, 54:(8) 967-972.

Schiel, D. R.; Steinbeck J. R. and Foster, M. S. (2004). Ten years of induced ocean warming causes comprehensive changes in marine benthic communities. Ecology, 85 (7): 1833-1839.

Serour, R. K. (2004) An Environmental Economic assessment of the Impacts of Recreational SCUBA Diving on Coral Reef Ecosystem in Hurghada, the Red Sea, Egypt. M.Sc. Thesis, University of Maryland, Collage Park, US, pp 76.

Sheppard, C. R.C. (2003). Predicted recurrences of mass coral mortality in the Indian Ocean. Nature 425: 294-297.

Spalding, M.D.; Ravilious, C. and Green, E.P. (2001). World Atlas of Coral Reefs. Prepared at the UNEP World Conservation Monitoring Centre. University of California Press, Berkeley, USA.

Subade, R. F. (2007). Mechanisms to capture economic values of marine biodiversity: the case of Tubbataha Reefs UNESCO World Heritage Site, Philippines. Mar Policy 31:135-142

Thomsen, M.S. and McGlathery, K. (2005). Facilitation of macroalgae by the sedimentary tube forming polychaete Diopatra cuprea. Estuar. Coast. Shelf Sci, 62: 63-73.

Torres, J. L. And Morelock, j. (2002). Effect of terrigenous sediment influx on coral cover and linear extension rates of three Caribbean massive coral species. Caribb. J. Sci, 38:222-229.

Tratalos, J. A. and Austin, T. J. (2001). Impacts of recreational SCUBA diving on coral communities of the Caribbean island of Grand Cayman. Biological Conservation,102: 67-75.

Van Katwijk, M. M.; Meier, N. F.; van Loon, R.; van Hove, E. M.; Giesen W. B. J. T. ; van der Velde, G. and den Hartog, C. (1993). Sabaki River sediment load and coral stress: correlation between sediments and condition of the MalindiWatamu reefs in Kenya (Indian Ocean). Marine Biology, 117: 675-683.

Vermeij, M. J. A; van Moorselaar, I.; Engelhard, S.; Hornlein, C. and Vonk, S. M. (2010) The Effects of Nutrient Enrichment and Herbivore Abundance on theAbility of Turf Algae to Overgrow Coral in the Caribbean. PLos ONE 5(12): e14312. doi:10.1371/journal.pone.0014312

Ward, S. and Harrison, P. (2000). Changes in gametogenesis and fecundity of acroporid corals that were exposed to elevated nitrogen and phosphorus during the ENCORE experiment. Journal of Experimental Marine Biology and Ecology, 246: 179-221.

West, K. and Van Woesik, R. (2001). Spatial and temporal variance of river discharge on Okinawa (Japan): Inferring the temporal impact on adjacent coral reefs. Marine Pollution Bulletin, 42: 864-872.

Wittenberg, M. and Hunte, W. (1992). Effects of eutrophication and sedimentation on juvenile corals. 1. Abundance, mortality and community structure. Marine Biology, 116: 131-138.

Woodland, D. and Hooper, N. (1977). The effect of human trampling on coral reefs. Biological Conservation, 11:1-4.

Woolfe, K.J. and Larcombe, P. (1998). Terrigenous sediments as a control upon reef development. In: Camoin, G.F., Davies, P.J. (Eds.), Reefs and Carbonate 
Platforms in the Pacific and Indian Oceans. Special Publication of the International Association of Sedimentologists, 25:295-310.

\section{ARABIC SUMMARY}

تاثير أنثطة الغوص على الحيود المرجانية للخلجان المحمية فى البحر الاحمر المصرى

$$
\text { قسم علوم البحار ـ كلبة العلوم- جامعة قحمودة السويس الآسماعيلية - جمهورية مصر العربيه }
$$

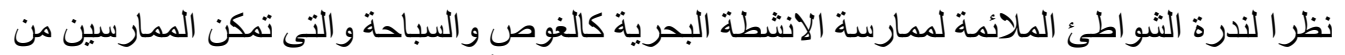

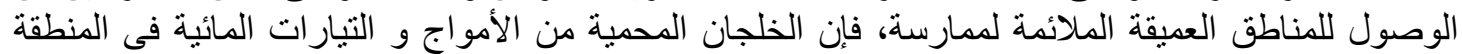

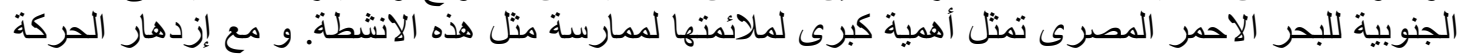

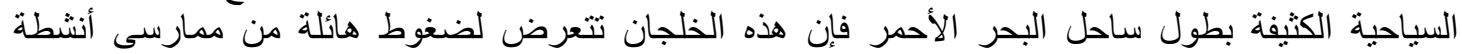

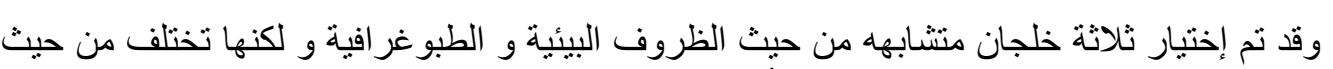

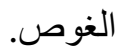

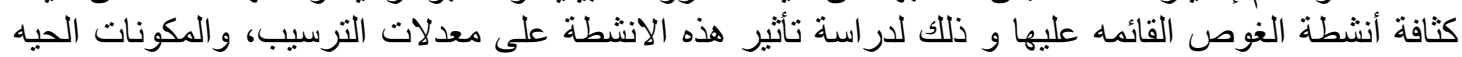

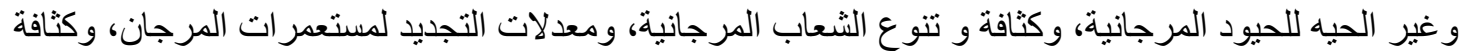
وتنوع أسماك الثعاب المرجانية.

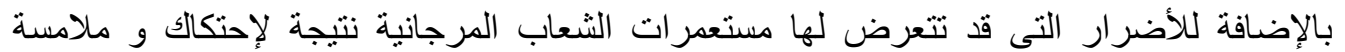

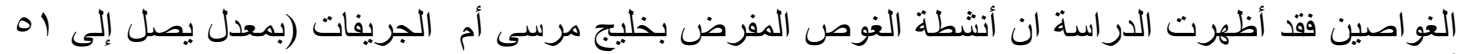

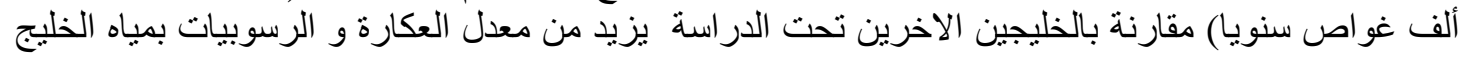

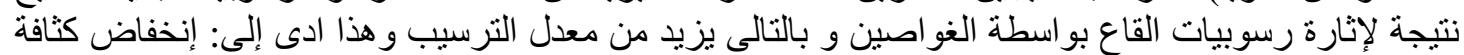

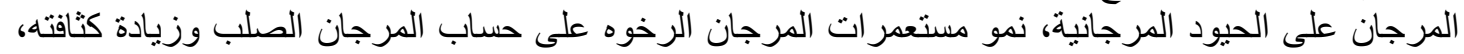

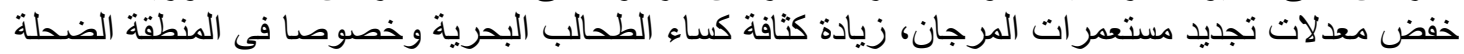

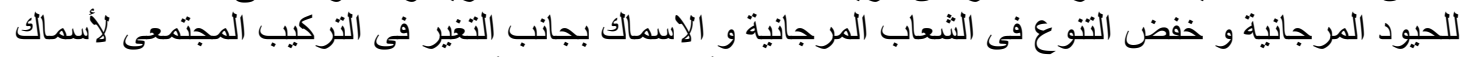

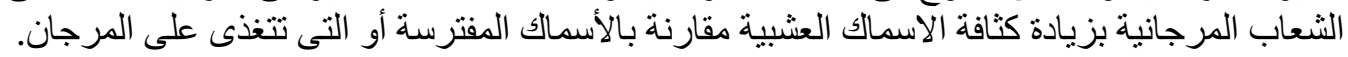

